\title{
Analysis of nutritional status and diet in children with cow's milk protein allergy on a milk elimination diet
}

\author{
Analiza stanu odżywienia i sposobu żywienia dzieci z alergią na białka mleka krowiego \\ pozostających na eliminacyjnej diecie bezmlecznej
}

\begin{abstract}
Aim: To analyse the somatic development and nutritional status of children with cow's milk protein allergy on a milk elimination diet. Material and methods: The study enrolled 46 children aged 13-36 months with cow's milk protein allergy diagnosis, following a milk elimination diet for 6 to 30 months. Exclusion criteria were chronic diseases. The control group included 30 healthy children of the same age. Somatic development was evaluated on the basis of anthropometric parameters, while nutritional status was based on Cole's index. Nutrition was analysed on the basis of a 3-day food record using the Dieta 5 programme. Results: $10.87 \%$ of children with cow's milk protein allergy and $16.67 \%$ of children in the control group were found to be underweight; $8.7 \%$ of children with cow's milk protein allergy and $10 \%$ of children in the control group were identified as overweight, and $6.52 \%$ of children with cow's milk protein allergy as obese. The evaluation of the examined children's nutritional status based on body mass index indicated that there were $13 \%$ of malnourished children in the study group and $20 \%$ in the control group. An analysis of the examined children's diets proved an excessive intake of protein, carbohydrates, sodium, phosphorus, magnesium, vitamins $\mathrm{A}$ and $\mathrm{C}$ in both of the groups, and vitamins $\mathrm{D}$ and $\mathrm{E}$ in the study group. The intake of fats, iron, vitamins C, E, D and fibre was higher in the study group than in the control group. Conclusions: The somatic development and nutritional status in the study group of children aged up to 3 years with cow's milk protein allergy on an elimination diet did not significantly differ from the respective parameters obtained in the control group of children. A thorough evaluation of the nutritional status and nutrition should be carried out in the course of check-ups in all children.
\end{abstract}

Keywords: nutritional status, cow's milk protein allergy, elimination diet, nutrition

Wstęp: Podstawową metodą leczenia alergii na białka mleka krowiego jest eliminacyjna dieta bezmleczna. Wykazano, że może ona prowadzić do niedoborów żywieniowych i zaburzeń rozwoju somatycznego. Cel pracy: Analiza rozwoju somatycznego, stanu odżywienia i sposobu żywienia dzieci z alergią na białka mleka krowiego, pozostających na diecie eliminacyjnej. Materiał i metody: Badaniem objęto 46 dzieci z alergią na białka mleka krowiego w wieku 13-36 miesięcy, u których stosowano dietę bezmleczną przez okres 6-30 miesięcy. Do grupy porównawczej zakwalifikowano 30 dzieci zdrowych w tym samym przedziale wiekowym, pozostających na diecie bez ograniczeń dietetycznych. Kryteriami wyłączenia były choroby przewlekłe. Rozwój somatyczny oceniano na podstawie parametrów antropometrycznych, stan odżywienia - w odniesieniu do wskaźnika masy ciała. Sposób żywienia analizowano przy użyciu programu Dieta 5. Wyniki: Niedobór masy ciała stwierdzono u 10,87\% dzieci $\mathrm{z}$ alergią na białka mleka krowiego i u 16,67\% dzieci z grupy porównawczej, nadwagę rozpoznano odpowiednio u 8,7\% i 10\% dzieci, a otyłość u 6,52\% dzieci z alergią na białka mleka krowiego. Niedobór wzrostu stwierdzono u 10\% dzieci z alergią na białka mleka krowiego i zdrowych. Ocena stanu odżywienia badanych dzieci w odniesieniu do wskaźnika masy ciała wykazała, że w grupie badanej niedożywionych było 13\% dzieci, a w grupie porównawczej 20\%. Analiza sposobu żywienia wykazała w porównaniu z normami żywienia nadmierne spożycie białka, węglowodanów, sodu, fosforu, magnezu, witamin A i C w obu grupach, a dodatkowo witamin D i E w grupie badanej. Spożycie energii i wapnia było prawidłowe w obu grupach. Podaż tłuszczów, żelaza, witamin D, C, E oraz błonnika pokarmowego w diecie eliminacyjnej była istotnie wyższa w stosunku do diety stosowanej u dzieci zdrowych. Wnioski: W grupie dzieci z alergią na białka mleka krowiego pozostających na diecie eliminacyjnej rozwój somatyczny i stan odżywienia nie różniły się w sposób istotny od analogicznych parametrów odnotowanych u dzieci z grupy porównawczej. W obu grupach stwierdzono nieprawidłowości w sposobie żywienia. 


\section{INTRODUCTION}

A llergic diseases are one of the most fundamental health problems of contemporary society. The frequency of cow's milk protein allergy (CMPA) in the paediatric population is estimated to be $1.9-4.9 \%$ and has been constantly increasing according to epidemiological research ${ }^{(1,2)}$. The only effective way of treating CMPA is a milk elimination $\operatorname{diet}^{(3)}$. However, it has been demonstrated that a milk-free diet can lead to impaired somatic development due to unjustified dietary restrictions and unintended dietary mistakes ${ }^{(4)}$. In addition, prolonged use of a milk-free diet without provocation tests to capture the moment when cow's milk protein tolerance develops has been observed. The nutritional status of children with CMPA is also affected by food allergy symptoms such as vomiting, diarrhoea, abdominal pain, lack of appetite, feeding disturbances and lack of acceptance and consumption of only small amounts of milk replacement formulas ${ }^{(5)}$. The risk of malnutrition is particularly important in children aged up to 3 years. According to the nutritional programming theory, the first 1,000 days of life are a critical period for the development of a young body, with intensive brain development, formation of the immune system, maturation of the gastrointestinal system and metabolic programming ${ }^{(6)}$. Nutritional interventions in this particular period of life can affect the risk of lifestyle diseases in adulthood $^{(7)}$. For this reason, current reports focus on the need to monitor the somatic development and nutritional status of children on a milk elimination $\operatorname{diet}^{(8)}$.

The aim of this study was to analyse somatic development, nutritional status and diet of children up to 3 years of age with CMPA treated with a milk elimination diet.

\section{MATERIAL AND METHODS}

The study included 46 children ( 25 boys and 21 girls) aged 13-36 months (mean age $20.22 \pm 6.51$ months) with an established CMPA diagnosis who had been on a milk elimination diet for 6-30 months. The control group included 30 healthy children ( 18 boys and 12 girls) in the same age range (mean age $21.43 \pm 5.64$ months) on an unrestricted diet with a history of exclusive breastfeeding up to 6 months of age. The subjects were patients of the Department of Allergology, Gastroenterology and Child Nutrition of the Medical University of Lodz, Łódź, Poland. Exclusion criteria were chronic diseases that can affect nutritional status. Data regarding the course of CMPA and the children's diet were obtained through a detailed interview and a questionnaire developed by the present authors that was administered to the parents/legal guardians of children taking part in the study. In all children, the following anthropometric measurements were taken: body mass (rounded to the nearest $0.1 \mathrm{~kg}$ ), body height (rounded to the nearest $0.1 \mathrm{~cm}$ ), head and arm circumference (rounded to the near- were compared with growth charts developed by the World Health Organization (WHO) for the assessment of growth in children aged $0-5$. Based on somatic measurements body mass index (BMI) was calculated according to the following formula:

body mass $[\mathrm{kg}]$

Body mass index $(\mathrm{BMI})=\frac{\text { height }[\mathrm{m}]^{2}}{}$

The BMI results were interpreted using growth charts developed by WHO. BMI values below the $5^{\text {th }}$ centile were adopted as a criterion for malnutrition, BMI between the $5^{\text {th }}$ and $85^{\text {th }}$ centile was considered normal body mass, BMI between the $85^{\text {th }}$ and $95^{\text {th }}$ centile as overweight and BMI over the $95^{\text {th }}$ centile as obesity.

The subjects' diet was rated based on a 3-day food log in which the children's parents/legal guardians recorded the amount and type of food and drink consumed by the child and meal hours. Portion size was estimated by the parents based on widely used measurements (usually weight and volume) and data provided by food manufacturers. The intake of selected nutrients was analysed using the computer programme Dieta 5 in accordance with food research methodology in place. The mean consumption of different nutrients was compared with the current recommended dietary allowances for healthy children in Poland.

Statistical analysis was performed using statistical packages STATISTICA PL 10 and SPSS 21. Qualitative variables were expressed with the number of observations of different variants of a particular feature $(N)$ with the corresponding percentage (\%). Two independent groups were compared using the Student's $t$-test or the non-parametric Mann-Whitney $U$ test. Results with $p<0.05$ were considered statistically significant. The study plan received a positive opinion of the Medical University of Lodz Ethics Committee (Resolution No. RNN/78/13/KE of 12.03.2013). Parents/legal guardians of the subjects provided written consent to participation in the study on behalf of the children.

\section{RESULTS}

Anthropometric measurements and BMI results and their centile distribution are presented in Figs. 1-5. No statistically significant differences were found in the analysed anthropometric parameters of nutritional status between the group of children with CMPA and the control group.

Weight deficiency was found in $10.87 \%$ of children with CMPA and in $16.67 \%$ of children from the control group, while overweight was observed in $8.7 \%$ of children with CMPA and in $10 \%$ of children from the control group; obesity was found in $6.52 \%$ of children with CMPA (Fig. 1). Normal body height was found in $34.79 \%$ of children from the study group and $43.33 \%$ of children from the control group and short stature was found in $10.87 \%$ of children from the study group and $10 \%$ of healthy children (Fig. 2). 


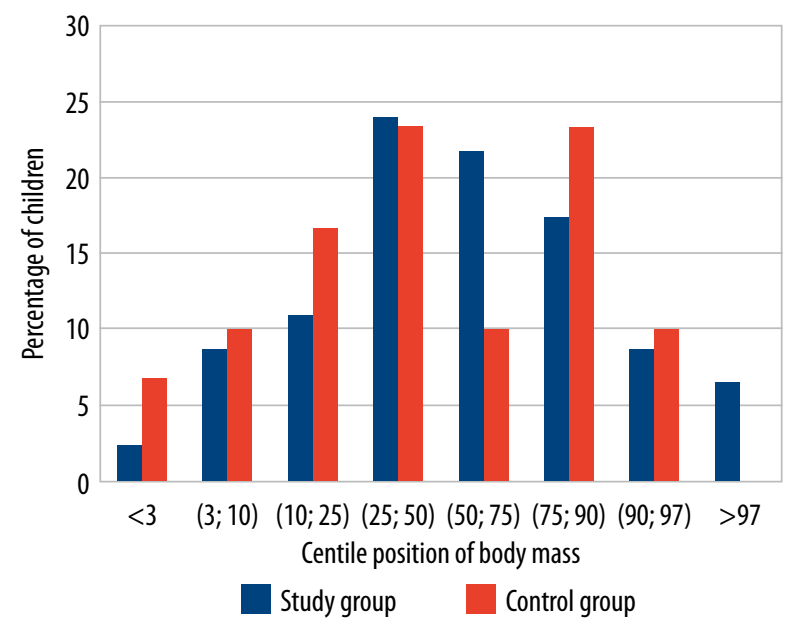

Fig. 1. Centile distribution of body mass in the study group and the control group

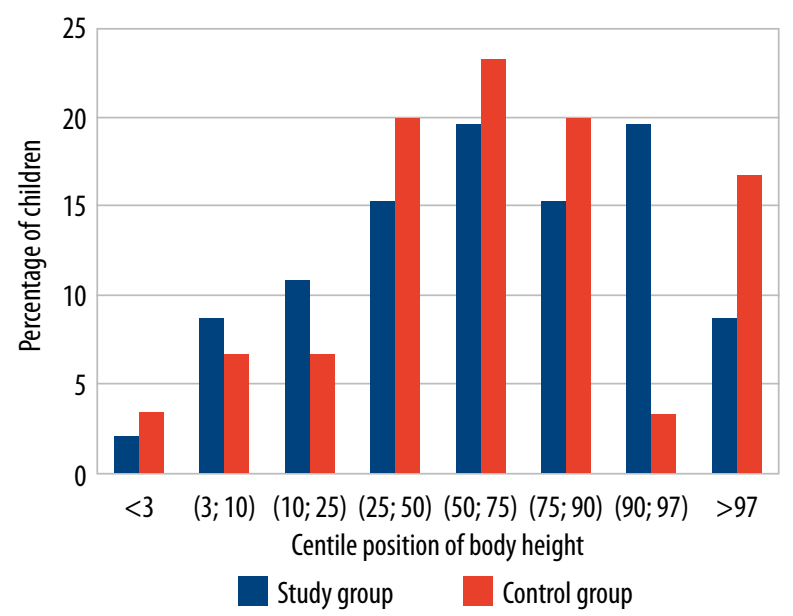

Fig. 2. Centile distribution of body height in the study group and the control group

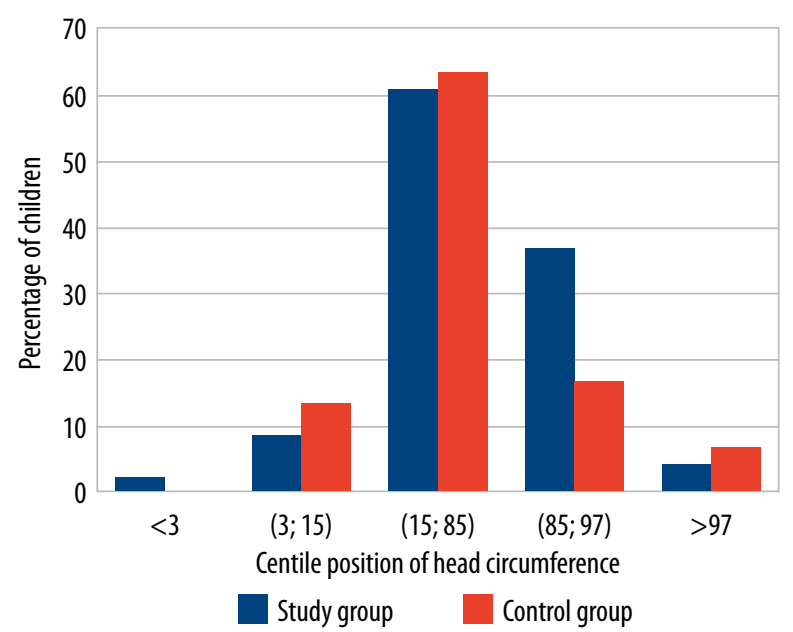

Fig. 3. Centile distribution of head circumference in the study group and the control group

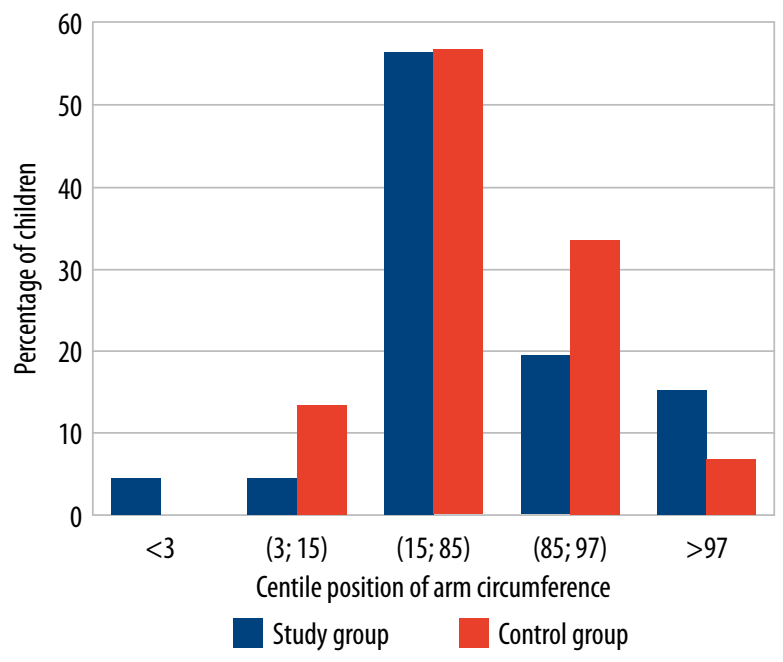

Fig. 4. Centile distribution of arm circumference in the study group and the control group

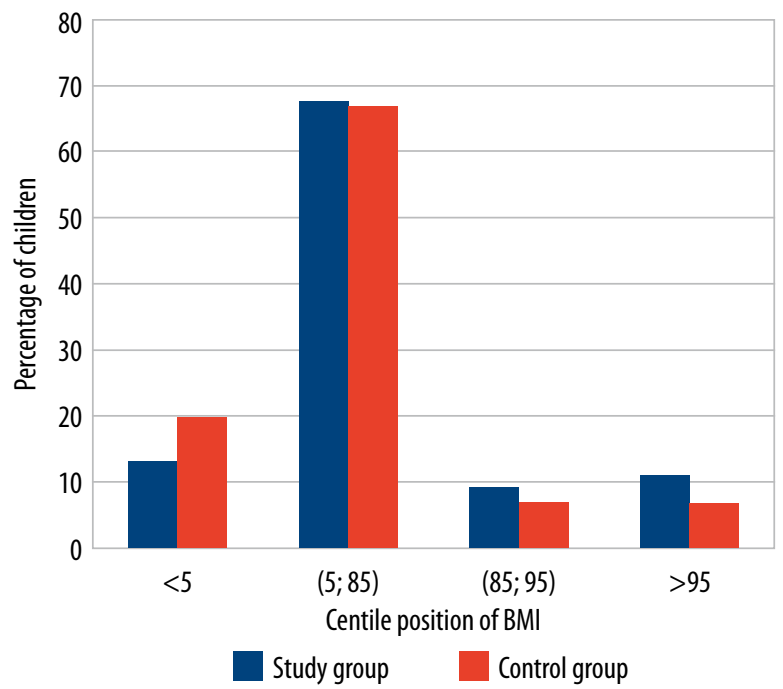

Fig. 5. Centile distribution of BMI in the study group and the control group

The analysis of centile positions of head circumference values revealed 1 child from the study group being below the $3^{\text {rd }}$ centile; normal head circumference was observed in $60 \%$ of children from the study group and the control group. Head circumference values over the $97^{\text {th }}$ centile was found in 2 children from the study group and 2 from the control group (Fig. 3).

Based on the centile distribution of arm circumference values it was found that a similar proportion of children (56.67\% of the control group and $56.52 \%$ of the study group) had an arm circumference within the wide normal range $\left(15^{\text {th }}-85^{\text {th }}\right.$ centile $)$. In the study group, $4.35 \%$ of children had an arm circumference below the $3^{\text {rd }}$ centile and in $15 \%$ of children the value was over the $97^{\text {th }}$ centile (Fig. 4 ). The majority of subjects had a normal body mass as per BMI (67\% of children from the study group and $66 \%$ of children from the control group). There was a higher proportion of malnourished children in the control group 
(20\%) compared to the study group (13\%). Overweight and obesity were observed to be more common in the study group (19\% in total) than the control group (13\%). No statistically significant differences were found between the two groups (Fig. 5).

A detailed analysis of the children's diets using food interview supported by Dieta 5 software demonstrated a large number of problems in the nutrition of children with CMPA and those from the control group. Excessive consumption of protein, carbohydrates, sodium, phosphorus, magnesium and vitamins $\mathrm{A}$ and $\mathrm{C}$ was found in both groups and of vitamins $\mathrm{D}$ and $\mathrm{E}$ in the study group with reference to dietary norms for children aged between 1 and 3 years developed by the Polish Expert Group (Tab. 1). Energy and calcium consumption was normal in both groups. The intake of fats, iron, vitamins D, C and E and fibre in elimination diet was significantly higher than in the diet of healthy children.

\section{DISCUSSION}

Elimination diet used in the treatment of CMPA involves excluding the harmful food from the child's diet (milk and milk products) and replacing it with food of an equivalent nutritional value (a milk-replacement formula) in order to ensure an appropriate dietary balance. Literature data show that prolonged use of a strict diet may increase the risk of weight deficiency and growth disorders due to calorie and nutrient deficiencies ${ }^{(9-12)}$. According to expert recommendations, basic anthropometric parameters and diet should be regularly assessed in terms of quantity and quality ${ }^{(8)}$.

The present study revealed weight and height deficiency in $10.87 \%$ of children, including 1 child with severe malnutrition.
The aetiology and pathogenesis of malnutrition associated with CMPA involves a decreased intake of food due to loss of appetite and severe vomiting following milk consumption; another factor is chronic diarrhoea associated with enteropathy that presents with intestinal villous atrophy, and secondary disorders of digestion and absorption of different nutrients (malabsorption) ${ }^{(13)}$. Growth disorders are attributed to the presence of inflammation which increases energy demand of the body and the production of cytokines [interleukin 6 (IL-6) and tumour necrosis factor (TNF- $\alpha$ )]; these cytokines inhibit growth by reducing the sensitivity of cells to growth hormone and insulin-like growth factor ${ }^{(14)}$. Observations of other authors regarding the effects of elimination diet on the nutritional status of children with CMPA demonstrated weight deficiency in $18.3 \%$ of them ${ }^{(15)}$. Hill et al. found as many as $22 \%$ of children with diagnosed CMPA to be underweight ${ }^{(16)}$. In a study on nutritional status of 100 children with food allergy, Meyer et al. diagnosed weight deficiency in $11.5 \%$ of subjects ${ }^{(17)}$.

The problem of weight deficiency is also found in healthy children. In the present study, the proportion of children with weight deficiency was $13.37 \%$, which was higher in the control group than in patients with CMPA; in 2 of those children extreme malnutrition was diagnosed. A similar rate of malnutrition was demonstrated in a Polish nationwide nutritional status study of children aged 13-36 months, in which malnutrition was found in $12.5 \%$ and extreme malnutrition was observed in $14.5 \%$ of subjects ${ }^{(18)}$. Based on epidemiological research, the rate of malnutrition among children up to 3 years of age is estimated to be approximately $27 \%^{(19)}$; the rate among children with CMPA is $4-26.7 \%$ according to different authors ${ }^{(15,20)}$.

Overweight and obesity are at the other end of the nutritional continuum. Currently, overweight and obesity in

\begin{tabular}{|c|c|c|c|c|}
\hline \multirow{2}{*}{ Nutrients } & \multicolumn{4}{|c|}{$\begin{array}{c}\text { Mean daily intake } \\
\text { Mean } \pm S D\end{array}$} \\
\hline & Study group & Control group & Recommended amounts & $p$ \\
\hline Energy [kcal] & $1,113.46 \pm 198.36$ & $1,037.77 \pm 173.15$ & $1,000 \pm 10 \%$ & 0.0919 \\
\hline Protein $[\mathrm{g}]$ & $44.95 \pm 10.19$ & $46.07 \pm 12.54$ & $25-30$ & 0.2665 \\
\hline Fats [g] & $35.10 \pm 7.73$ & $30.20 \pm 8.24$ & $33-39$ & 0.0103 \\
\hline Carbohydrates [g] & $160.32 \pm 33.56$ & $151.07 \pm 27.44$ & $130.0 \pm 10 \%$ & 0.2120 \\
\hline Sodium [mg] & $1,589.33 \pm 418.48$ & $1,735.53 \pm 501.90$ & 750 & 0.1732 \\
\hline Potassium [mg] & $1,678.67 \pm 399.98$ & $1,594.87 \pm 377.22$ & 2,400 & 0.3643 \\
\hline Calcium [mg] & $486.39 \pm 117.06$ & $487.13 \pm 156.64$ & 500 & 0.9812 \\
\hline Phosphorus [mg] & $700.94 \pm 130.20$ & $685.93 \pm 183.35$ & 460 & 0.6592 \\
\hline Magnesium [mg] & $143.11 \pm 34.92$ & $139.87 \pm 38.24$ & 80 & 0.6785 \\
\hline Iron [mg] & $10.46 \pm 2.62$ & $7.45 \pm 2.39$ & 7 & 0.0000 \\
\hline Vitamin C [mg] & $86.34 \pm 26.06$ & $52.90 \pm 22.52$ & 40 & 0.0000 \\
\hline Vitamin A [ $\mu \mathrm{g}]$ & $861.41 \pm 309.92$ & $838.67 \pm 597.75$ & 400 & 0.1313 \\
\hline Vitamin E [mg] & $8.12 \pm 2.19$ & $4.46 \pm 2.18$ & 6 & 0.0000 \\
\hline Vitamin D [ $\mu \mathrm{g}]$ & $7.74 \pm 2.95$ & $4.31 \pm 3.29$ & 5 & 0.0000 \\
\hline Fibre [g] & $11.07 \pm 3.48$ & $9.04 \pm 2.66$ & $10-15$ & 0.0083 \\
\hline
\end{tabular}

Tab. 1. Mean daily intake of nutrients by children from the study group and the control group 
children are an important problem due to their increasing prevalence. In Poland, $14.5 \%$ of children up to 3 years of age were found to be overweight and $13 \%$ were found to be obese ${ }^{(18)}$. These alarming data on the prevalence of obesity have been corroborated by the present study, in which $8.7 \%$ of children from the study group were found to be overweight and $6.52 \%$ obese, while $10 \%$ of healthy children were found to be overweight. These figures are consistent with the ones presented by other authors ${ }^{(15,18,21)}$.

Arm circumference is considered to be a sensitive indicator of protein nutrition, which makes it possible to diagnose somatic development abnormalities resulting from improper nutrition $^{(15)}$. In the present study, a normal arm circumference was observed in more than half of subjects from both groups. Poorer protein nutritional status (arm circumference below the $15^{\text {th }}$ centile) was diagnosed in $8.7 \%$ of children from the study group and $13.33 \%$ of children from the control group.

In studies by Tiainen et al. and Medeiros et al. on the nutritional status of children on a milk-free diet versus children on an unrestricted diet, BMI values were statistically lower in children with CMPA than in healthy children ${ }^{(10,12)}$. The results of the present study are different. Malnutrition as per BMI was diagnosed in 13\% of children with CMPA and in as many as $20 \%$ of healthy children.

Malnutrition in children with CMPA may be caused by an unbalanced diet in terms of quantity and quality. Malnutrition is usually associated with weight deficiency. However, if there is an insufficient intake of basic nutrients, malnutrition is qualitative in nature and can occur in children with normal weight or overweight ${ }^{(22)}$. Once any sources of cow's milk protein have been excluded from a small child's diet, appropriate milk replacement products should be selected in order to ensure a sufficient supply of calcium and phosphorus compounds, riboflavin, pantothenic acid, vitamin $\mathrm{B}_{12}$, vitamin $\mathrm{A}$ and vitamin $\mathrm{D}$ from alternative sources ${ }^{(23)}$. Children with hypersensitivity to cow's milk protein often do not accept the taste and smell of milk replacement formulas and have an aversion towards other foods introduced into their diet, which is the cause of insufficient intake of different nutrients. Insufficient calorie supply in the food consumed leads to attenuated growth in children ${ }^{(11)}$. In the present study, the mean daily energy consumption was within dietary norms for children. However, there are studies in the literature in which children on an elimination diet have a significantly lower energy intake ${ }^{(9,12)}$.

In the present study, all children were found to consume too much protein, which is a risk factor for overweight and obesity according to the latest reports. These results are consistent with nutritional studies conducted by other authors, in which protein consumption in children with CMPA exceeded dietary norms ${ }^{(21,24)}$. Similar observations are presented by Buczek et al. in their study, in which protein consumption was $33.4 \mathrm{~g}$ in children with food allergy (144\% of the norm) at 2 years of age and $39.8 \mathrm{~g}$ (142\% of the norm) at 3 years of age ${ }^{(20)}$.
Alarming observations regarding excessive sodium and simple sugar consumption by the youngest children have been corroborated by the present study. A relationship between excessive sodium consumption and the development of hypertension, cardiovascular diseases and kidney diseases has been demonstrated ${ }^{(25)}$. Research clearly shows that over $90 \%$ of children in Poland consume too much salt, as much as twice the recommended intake ${ }^{(18)}$. This is due to adding salt to meals during their preparation and to high sodium content in ready food products (baked goods, cold cuts, breakfast cereals). The consequences of excessive carbohydrate consumption include overweight, obesity, type 2 diabetes and tooth decay and the promotion of inappropriate taste preferences ${ }^{(26)}$. According to expert recommendations, neither salt nor sugar should be used for the preparation of meals for infants and younger children ${ }^{(27)}$.

During the use of a milk-free diet, calcium-phosphorus balance and bone mineralisation may become impaired. The right supply of calcium and vitamin $\mathrm{D}$ in children's diet during the first 3 years of life has a direct impact on the achievement of peak bone mass ${ }^{(28)}$. In the current study, a decreased calcium intake in relation to the recommended target was found in $56 \%$ of the subjects, while vitamin D intake was significantly higher in children with CMPA. The mean daily intake of calcium is consistent with the results obtained by other authors, who recorded the mean daily intake of calcium in children with CMPA aged 13-24 months to be $546 \pm 170 \mathrm{mg}$ and $420 \pm 227 \mathrm{mg}$ in older children (25-36 months) ${ }^{(20)}$. An interesting study comparing diets of children with CMPA and those of healthy children also documented a larger mean vitamin D intake in children on a milk-free $\operatorname{diet}^{(24)}$. The available literature reports indicate that the intake of vitamins $\mathrm{A}, \mathrm{E}$ and $\mathrm{C}$ in the diets of healthy children exceeds the recommended targets ${ }^{(18)}$. The present study also revealed excessive vitamin A and $\mathrm{C}$ intake (in both groups); vitamin E consumption was significantly higher in children on an elimination diet. Weker et al. found vitamin $\mathrm{A}$ and $\mathrm{C}$ intake to be excessive in as many as $90 \%$ of studied children aged up to 3 years ${ }^{(26)}$. Often being unaware of possible side effects, parents enrich their children's diet with vitamin and mineral supplements without doctor's advice. Apart from vitamin and mineral formulations, excessive vitamin intake is caused by children's food fortified with vitamins and minerals. Examples of fortified foods include vitamin A-fortified margarines, milk products fortified with vitamin $\mathrm{D}$, fruit juices, desserts and fruit drinks with vitamin $\mathrm{C}$ and baby porridges and breakfast cereals with added group B vitamins, calcium and iron. The use of multivitamin supplements on top of fortified products may lead to overdose of particular vitamins and minerals.

The present detailed analysis of children's diets has led to the conclusion that both groups of children (with CMPA and without it) had a poorly varied, monotonous diet with low amounts of wholegrain products and fruit and vegetables. The subjects received highly processed foods too early, 
which contain excessive amounts of simple sugars and salt. Early childhood is the time when food preferences and habits develop. The numerous dietary mistakes revealed by the present study may be the cause of inappropriate food behaviour in adulthood and predispose individuals to civilisation diseases; therefore, education on a healthy diet should be constantly provided to all parents and legal guardians.

\section{CONCLUSIONS}

1. The children taking part in the study were found to have an abnormal nutritional status: $10.87 \%$ of children with CMPA and $16.67 \%$ of children from the control group were malnourished; overweight and obesity were less common $(8.7 \%$ of children with CMPA and $10 \%$ of children from the control group were overweight and 6.52\% of children with CMPA were obese). The differences between the groups were not statistically significant.

2. Based on diet analysis using the Dieta 5 computer programme, dietary problems were revealed in both groups such as, in particular, excessive consumptions of protein, carbohydrates, sodium, phosphorus and vitamins $\mathrm{A}$ and $\mathrm{C}$.

3. The parents/legal guardians of the subjects have an insufficient knowledge on dietary recommendations. Therefore, urgent educational efforts should be undertaken in order to limit disorders of somatic development and to prevent civilisation diseases.

\section{Conflict of interest}

The authors do not report any financial or personal affiliations to persons or organisations that could adversely affect the content of or claim to have rights to this publication.

\section{References}

1. Prescott S, Allen KJ: Food allergy: riding the second wave of the allergy epidemic. Pediatr Allergy Immunol 2011; 22: 155-160.

2. Nwaru BI, Hickstein L, Panesar SS et al.; EAACI Food Allergy and Anaphylaxis Guidelines Group: The epidemiology of food allergy in Europe: a systemic review and meta-analysis. Allergy 2014; 69: 62-75.

3. Fiocchi A, Brozek J, Schünemann $\mathrm{H}$ et al.; World Allergy Organization (WAO) Special Committee on Food Allergy: World Allergy Organization (WAO) Diagnosis and Rationale for Action against Cow's Milk Allergy (DRACMA) Guidelines. Pediatr Allergy Immunol 2010; 21 Suppl 21: 1-125.

4. Mehta H, Ramesh M, Feuille E et al.: Growth comparison in children with and without food allergies in 2 different demographic populations. J Pediatr 2014; 165: 842-848.

5. Mehta $\mathrm{H}$, Groetch $\mathrm{M}$, Wang J: Growth and nutritional concerns in children with food allergy. Curr Opin Allergy Clin Immunol 2013; 13: 275-279.

6. Barker DJ, Eriksson JG, Forsén T et al.: Fetal origins of adult disease: strength of effects and biological basis. Int J Epidemiol 2002; 31: 1235-1239.

7. Koletzko B, Desci T, Molnár D et al. (eds.): Early Nutrition Programming and Health Outcomes in Later Life: Obesity and Beyond. Springer, New York 2009.
8. Giovannini A, D’Auria E, Caffarelli C et al.: Nutritional management and follow up of infants and children with food allergy: Italian Society of Pediatric Nutrition/Italian Society of Pediatric Allergy and Immunology Task Force Position Statement. Ital J Pediatr 2014; 40: 1.

9. Henriksen C, Eggesbø M, Halvorsen R et al.: Nutrient intake among two-year-old children on cow's milk-restricted diets. Acta Paediatr 2000; 89: 272-278.

10. Tiainen JM, Nuutinen OM, Kalavainen MP: Diet and nutritional status in children with cow's milk allergy. Eur J Clin Nutr 1995; 49: 605-612.

11. Christie L, Hine RJ, Parker JG et al.: Food allergies in children affect nutrient intake and growth. J Am Diet Assoc 2002; 102: 1648-1651.

12. Medeiros LCS, Speridião PGL, Sdepanian VL et al.: [Nutrient intake and nutritional status of children following a diet free from cow's milk and cow's milk by-products]. J Pediatr (Rio J) 2004; 80: 363-370.

13. Kaczmarski M, Uścinowicz M, Daniluk U: Niedożywienie organizmu a nadwrażliwość pokarmowa. Stand Med 2004; 1: 204-206.

14. Moreno Villares JM, Oliveros Leal L, Torres Peral R et al.: [A follow-up study of growth in infants with cow's milk allergy]. An Pediatr (Barc) 2006; 64: 244-247.

15. Adamska I, Świątek K, Czerwionka-Szaflarska M et al.: Wpływ eliminacyjnej diety bezmlecznej na stan odżywienia dzieci do ukończenia drugiego roku życia. Pediatr Współcz 2007; 9: 29-36.

16. Hill DJ, Murch SH, Rafferty K et al.: The efficacy of amino acidbased formulas in relieving the symptoms of cow's milk allergy: a systematic review. Clin Exp Allergy 2007; 37: 808-822.

17. Meyer R, Venter C, Fox AT et al.: Practical dietary management of protein energy malnutrition in young children with cow's milk protein allergy. Pediatr Allergy Immunol 2012; 23: 307-314.

18. Weker H, Barańska M, Dyląg $\mathrm{H}$ et al.: Analysis of nutrition of children aged 13-36 months in Poland: a nation-wide study. Med Wieku Rozwoj 2011; 15: 224-231.

19. Szponar L, Ołtarzewski M: Epidemiologia niedożywienia dzieci i młodzieży w Polsce. Pediatr Współcz Gastroenterol Hepatol Żyw Dziecka 2004; 6: 13-17.

20. Buczek S, Kamer B, Pasowska R et al.: Ocena sposobu żywienia niemowląt i małych dzieci z alergią pokarmową. Pediatr Współcz Gastroenterol Hepatol Żyw Dziecka 2006; 8: 175-179.

21. Walczak M, Grzelak T, Kramkowska M et al.: Ocena sposobu żywienia i stanu odżywienia dzieci z alergią na białka mleka krowiego - badania pilotażowe. Now Lek 2013; 82: 124-129.

22. Noimark L, Cox HE: Nutritional problems related to food allergy in childhood. Pediatr Allergy Immunol 2008; 19: 188-195.

23. Mofidi S: Nutritional management of pediatric food hypersensitivity. Pediatrics 2003; 111: 1645-1653.

24. Gołębiowska-Wawrzyniak M, Rowicka G, Strucińska M et al.: Ocena stanu odżywienia i sposobu żywienia dzieci z alergią na białka mleka krowiego. Alergoprofil 2012; 8: 20-28.

25. Lava S, Bianchetti MG, Simonetti GD: Salt intake in children and its consequences on blood pressure. Pediatr Nephrol 2015; 30: 1389-1396.

26. Weker $\mathrm{H}$, Barańska $\mathrm{M}$, Riahi $\mathrm{A}$ et al.: Wzory żywienia niemowląt i małych dzieci - badanie ogólnopolskie. Stand Med Pediatr 2014; 11: 417-427.

27. Szajewska H, Socha P, Horvath A et al.: Zasady żywienia zdrowych niemowląt. Zalecenia Polskiego Towarzystwa Gastroenterologii, Hepatologii i Żywienia Dzieci. Stand Med Pediatr 2014; 11: 321-338.

28. Fox MK, Reidy K, Novak $\mathrm{T}$ et al.: Sources of energy and nutrients in the diets of infants and toddlers. J Am Diet Assoc 2006; 106 (1 Suppl 1): S28-S42. 